\title{
地場産農産物を活用した学校給食の取組と効果に関する一考察
}

一高知県南国市を事例として一

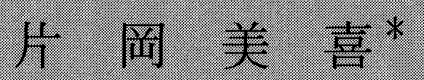

\section{An Examination of the Practices and Effects of the School-meal Program Using Local}

\author{
Food Products: A Case Study of Nankoku City, Kochi Prefecture
}

Miki Kataoka (The United Graduate School of Agricultural Sciences,

Ehime University • SPS Research Fellow)

Food products used in the school-meal program are usually supplied by the wholesale system, organized nationally in Japan. However, the movement attempting to use local food products in the program has appeared in recent years. This paper examines the process and effects of this practice by a case study of the program in Nankoku city, Kochi prefecture, which is well known as a pioneer in the practice.

Some meaningful results have been found in this work. Firstly, the use of rice, fruits and vegetables, produced in hilly and mountainous regions in the area under study has substantially promoted the development of agriculture. Secondly, these practices have brought about significant effects both on cost-saving in the school meal and in school education. The efforts of school dieticians in food material use have greatly contributed to cost saving.

This analysis also suggests that further efforts are needed both in guaranteeing the supply of local food products, and in improving the mutual understanding between food suppliers and the education-side.

\section{1. はじめに}

地場産農産物 1) を活用した学校給食は,「地産地 消」2）の実践的な取組の一つとして, 近年広がりを 見せている. 1990 年代後半にこれまで国庫補助に 支えられてきた給食用食材供給体制が転換傾向を見 せたことや，「食料・農業・農村基本計画」（2000 年)において食料自給率向上に関する指針が示され た政策的な流れとともに, 食への安全・安心志向の 高まりから, 消費者と生産者の相互理解を深める取 組として注目を集めている。こうした流れを受け, 2002 年に文部科学省により地場産農産物を食材と する学校給食を積極的に推進する方向が示されたと ともに ${ }^{3}$, 食育問題が広範に論議され, 学校給食に

* 愛媛大学大学院連合農学研究科 ・ 日本学術振興会特別研究員
おける地場産率の向上が国是レベルでも重視される ようになっている4).

これらの動向を反映して, 学校給食に関する報道 や調査研究が多数見られるようになった ${ }^{5)}$. 例えば 根岸〔1]は, 学校給食による食嗜好への影響を分 析し, 食材供給に果たす農業関係者の役割の重要性 を指摘した. 中村・秋永〔2] は, 学校給食用食材 に占める「地場産自給率」の低さと地場産農産物導 入の関係を実態調查に基づいて考察し, 多くの課題 点を提起している. 片岡・胡 [3] は, 高知県南国 市の取組から地場産農産物を導入した学校給食の取 組に対する評価と課題を示し, 学校給食における地 産地消を「地域内の人・物の対流により, 市場経済 で評価されない価值 (農業の多面的機能, 教育的効 果など）が生まれる」とし，それらの取組は「地域 のムーブメント」であると位置付けた，続いて胡・ 
片岡〔4〕は，学校給食における地場産農産物の利 用と有機農業運動との関係を分析し, 地産地消を基 本とした学校給食の拡大を目指すには, 「有機」な どのコンセプトを明示的に示す必要があることを明 らかにした。

しかし, 実際の取組に比べて, 実証研究の成果は 全体としてまだ少なく, 多くの事例検証が必要であ る. 加えて近年の制度整備につれて, 多くの自治体 で取組が見られ始めているが，市町村合併等による 行政区の改編や財政削減に伴う学校給食の合理化の 動きなど，取組を支えてきた基盤を摇るがす状況が 発生している. そこで, 地場産農産物を利用した学 校給食を進展させていく上でも, より精緻で中長期 的視座に立った調査研究を積み上げてゆく必要があ ると言える.

したがって本稿の課題は, 地場産農産物を活用し た学校給食の先進事例として注目される ${ }^{6)}$ 高知県 南国市を取り上げ，展開過程の分析から取組の効果 と課題について考察を行うことにある. 既出論文 [3]においても南国市の事例を取り上げ, 2002 年ま での実態解明を行ったが，本稿ではさらに，取組の 社会経済的，制度的背景を明らかにするとともに， 対象地域の取組を段階的に捉え，それぞれの段階で 直面する問題とその発生要因, 具体的対応と効果, 地場産農産物の利活用への影響を捉え, 対象事例の 普遍的意義を見出すことを目指すものである．この ような分析によって学校給食における地場産農産物 の活用を推進する上で通有する効果と課題を提示 し, 今後発展する各地の取組に示唆を与えるものと 考える.

以下では，第 2 節において，我が国の学校給食制 度の変遷を概観し, 地場産農産物の学校給食への活 用が見られはじめた背景を整理する。第 3 節では, 対象地域における形成経緯, 食材供給, 食材活用と 食農教育の実態を取組の発展段階毎に明らかにす る. 第 4 節では, 地場産農産物を導入した学校給食 に期待される効果を三分類して, 取組による効果の 実態を考察する. 第 5 節では, 研究結果をまとめ, 今後の課題を指摘する.

\section{2. 学校給食制度の概要と地場産農産物を利用し た学校給食の展開}

政策による学校給食の計画的な導入は, 第二次世
界大戦後のことである. 戦後の困窮する食糧事情の 下で，児童・生徒の健全な成長のため，栄養補完を 図ることを目的に開始され，その後学校教育活動の 一環として位置付けられるようになった。1951 年, 当時の給食用財源であったガリオア資金（アメリカ の占領地域救済政府資金）の打ち切りに伴い，世論 の支持を得て国庫補助による学校給食の存続が要望 され，1954 年に学校給食法が成立した．以降，1966 年に「学校給食の物資の共同購入促進について（体 育局通知)」, 1975 年に「学校給食用物資安定供給対 策特別事業費」補助金 (12 億 5 千万円) の計上など, 物資の流通, 安定供給体制, 衛生管理を中心に, 普 及と充実のための施策が逐次実施されてきた。一連 の制度整備は，学校給食の普及に大きな成果を上げ, 2003 年度現在, 国公立校に打ける学校給食の普及 は, 全体で 1,067 万人の児童生徒が学校給食を受け, 小学校で $99.9 \%$, 中学校で $87.3 \%$ の割合に至り, 世 界的にみても高い給食実施率を実現している ${ }^{7}$.

このような給食実施状況が実現したのは, 学校給 食の効率化を目指して大きく二つの措置がなされた からである。一つは, 給食調理方式の合理化・大規 模化の推進である. 給食開始当初は, 個々の学校で 自校調理を行っていたが, 1985 年「学校給食業務の 運営の合理化（体育局通知）」を受け, 財政削減や 少子化への対応を目的に給食調理施設の集約化が進 んだ. 同通知以降, 調理施設の大型化に伴い, 調理 済給食の運搬業務, 食器洗浄, 給食用資材購入と管 理, ボイラー洗浄など給食管理業務の民間委託によ る合理化が進展している. 2003 度年現在, 学校数割 合で小学校が $50.8 \%$, 中学校が $66.5 \%$ で共同調理 場方式の完全給食を受けている.

もう一つは, 学校給食会の設置と組織化の推進で ある. 1955 年に日本学校給食会法が公布されてから の 5 年間で 47 都道府県すべてに学校給食会が設置 され, 特殊法人日本学校給食会 (現 (独) 日本ス ポーツ振興センター) を基幹とする全国的な組織網 が形成された。同会の目的は，学校給食用物資の適 正円滑な供給，学校給食の普及充実であり，買入， 売渡など給食用物資の供給に関する業務, 学校給食 に関する調査研究を主な業務としている.

図 1 は, 学校給食の組織システムを, 食材の流通 経路の視点から整理したものである. I 型の経路で は, 日本学校給食会が定めた学校給食用食材である 
指定物資および承認物資の供給が行われてきた．指 定物資とは，同会が学校給食用食材を安価で安定供 給を図るために, 文部科学大臣が指定した小麦, 米, 脱脂粉乳，牛肉など原材料とその加工品等である. 加えて，文部大臣の認可を得て取り扱う承認物資が あり, 加工食品, 冷凍食品など, 大量購入して保存 が可能なものが多種取り扱われた。このルートは給 食用物資供給の中で大きな比重を占めている.

青果物，加工食品，調味料などの食材について は， II 型の県学校給食会，III型の市町村学校給食会 など, 各自治体の学校給食会による調達が行われて いる，取引は，各自治体給食会と登録業者間による ものが中心である，IV型のように，中間経路をはさ まない調理場と供給側の直接的な取引は, 全体に占 める割合としては小さく, 市町村単位の学校給食会 を持たず,教育委員会が給食業務を代行している場 合などに見られる。

図 1 に示すように, これまでの学校給食制度では, $\mathrm{I} \sim$ III型を中心とした食材流通の整備によって物資 の共同購入が行われてきた。 これによって, 調理方 式の大規模化・合理化に対応した食材の安定供給対 策が徹底されたのみならず, 方針および事務処理系 統の一元化が図られ，保護者負担を抑えた安定的で 均質化された学校給食の供給に寄与してきた。

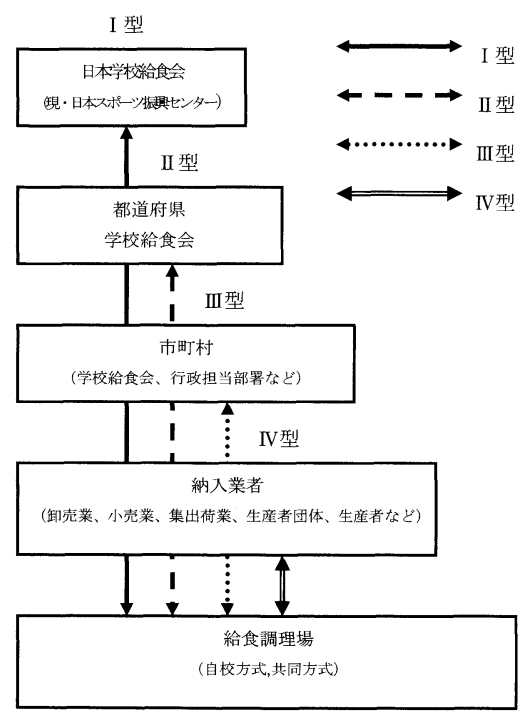

図 1. 学校給食用食材の流通系統 出所：参考文献 [5] を元に加筆・修正
その一方で, 同一規格品を大量に一括購入する傾 向は，地域で農業生産が行われているにも関わらず 地場産農産物の利用が極めて少ないという状況を形 成してきたため, 学校給食と地域農業はかい離の一 途を辿ることとなった。このような状況に対し，保 護者，教育関係者，一部有機農業者などを中心に， 安全な給食用食材の確保, 児童・生徒への教育的効 果, 流通経路の多様性確保等の観点から, 自治体等 へ地場産農産物の学校給食への導入を働きかける運 動が活発化するようになった ${ }^{8)}$. だが, これらの取 組は次節で取り上げる高知県南国市など一部の先進 事例に留まり, 1990 年代後半まで大きな広がりは見 られなかった。

取組が広がりを見せなかった要因は，食材の流通 経路の選択は学校給食会の方針によって強く規定さ れる場合が多く, 流通ルートの変更には, 食材納入 業者の既得権益の問題に直面するなどの障害がある からである. そして，食材購入に係る補助は，I 型 II 型の取り扱う範囲を対象に行われてきたため, 地 場産農産物など補助の対象外である経路は選択され てこなかった，その結果，学校給食会を中心とした 今日までの食材供給体制は, 量の確保, コストの面 から納入業者との計画的な大口取引が主体となり， 季節性のある小口の地場産農産物の納入が困難な流 通系統を形成することになった。

国内の農産物流通構造や態様も, 学校給食に少な からず影響している．野菜生産出荷安定法（1966 年）や卸売市場法（1971 年）に伴う流通の広域化に より，卸売市場の取引における地場産農産物の比重 が減退した。このような市場の傾向から, 納入業者 が仕入れを決定する際, 給食会から受注した数量と 価格が合致しない場合が多い地場産農産物は，おの ずと選択されなかった.

しかしながら近年の制度変化に伴い，これまで国 庫補助に依拠してきた食材供給体制は変化しつつあ る. 1997 年に閣議決定された「特殊法人の整理合理 化について」という通達に基づき，1998 年度のトマ トケチャップと精麦を最後に承認物資が廃止とな り, 同年から学校給食用米穀の值引き措置が段階的 廃止になっている。このように I 型は，食材供給業 務を縮小する一方，「学校給食における地場産物活 用事業」（2002 年）を開始し，情報提供などの支援 業務を拡大して, II・III型の各自治体給食会に食材 
供給業務を委譲している.このような近年の給食用 食材流通をとりまく環境变化は, 各自治体の学校給 食会ごとに個性が生まれる契機となり，特色のある 給食づくりが可能となり始めている.

\section{3. 高知県南国市の棚田米を活用した学校給食の 展開}

高知県南国市の取組は，先に述べた学校給食の大
きな流れの中で時代の要請を先取りし，早期から実 績をあげた先駆的事例である，同市の取組は，表 1 に示す三つの段階を経て, 既往とは異なる給食用米 穀の流通経路を形成し，南国方式と呼ばれる学校給 食を確立した.ここで取組を段階的に区分したのは, 学校給食において地場産農産物の活用を定着させる 条件および到達点が, 発展段階によって異なってい るからである.

表 1. 南国市における棚田米の学校給食への導入をめぐる取組年表

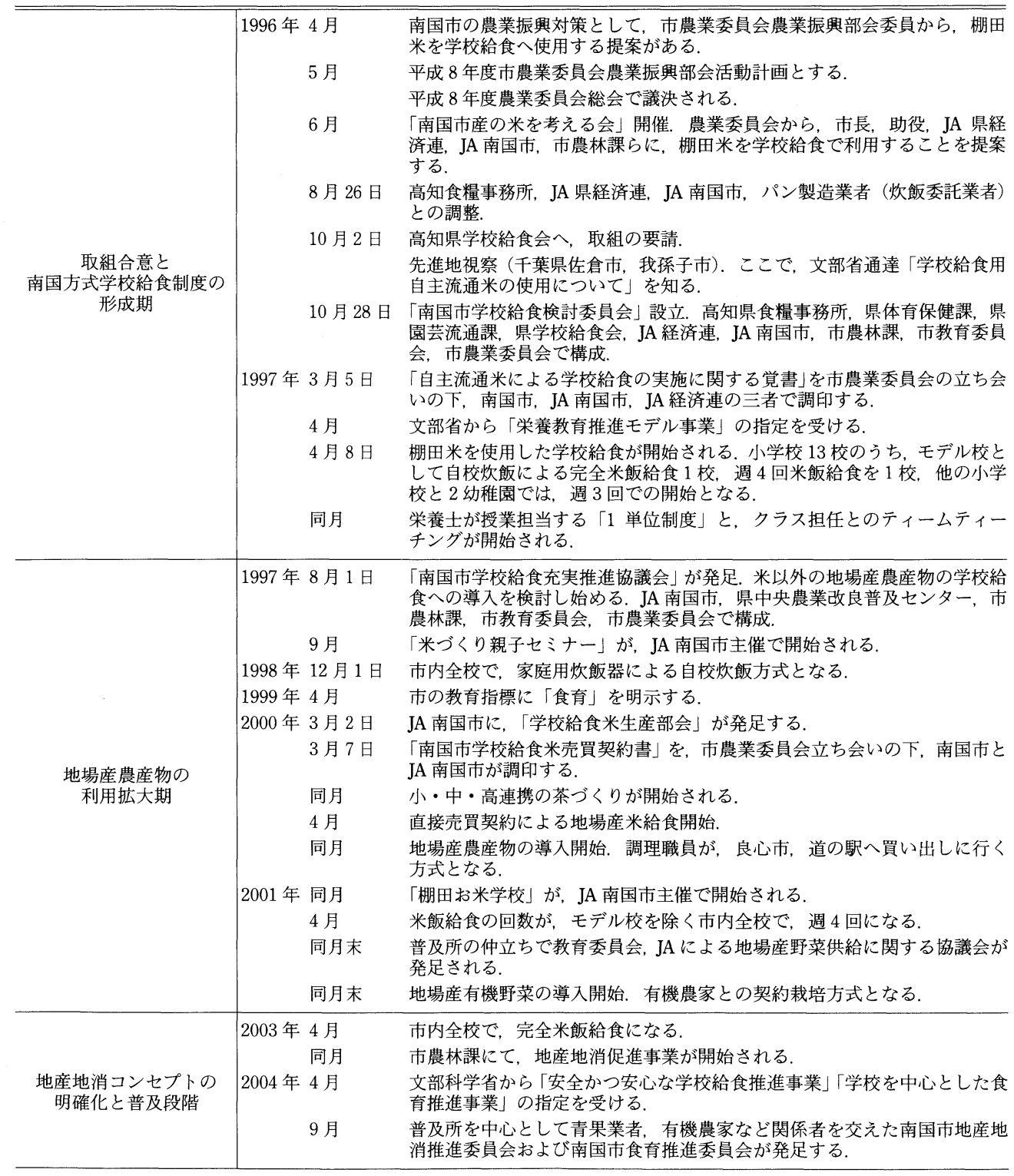


筆者は, 学校給食への地場産農産物の導入と定着 は, 抢よそ三つの段階を経て発展するものと考える. まず，第一段階では地場産農産物を給食用食材とし て継続的かつ安定的に供給する制度的な道筋をつけ ることを目的に，取組に対する関係者の合意と制度 的な整備を行うことを到達点とする. 第二段階では 地場産農産物の実質的な供給を目的に，更なる利用 拡大に向けた対策を講じること, 第三段階では取組 の継続的な普及と深化を目的に，学校給食に打ける 地産地消コンセンサスの醸成を行うことを発展の到 達点とする．以下では，先述した三つの発展段階に 従い，南国市方式学校給食の展開過程を整理する.

\section{（1）取組合意と南国方式学校給食制度の形成期}

（1996 年 4 月〜 1997 年 4 月）

南国方式の取組契機は，米価の急落と販路が見い だせない危機意識から，米の販路確保と中山間地域 農業の活性化策として学校給食への棚田米供給に着 目したことである．南国市内北部の中山間地域に位 置する上倉地区, 瓶岩地区では, 農業者の大半は 60 歳以上の高齢者で, 稲作と露地野菜の栽培を中心と した兼業農家が多く，典型的な中山間地域農業の特 徵を有している（表 2). 両地区の稲作は，かつて水 稲の二期作地帯である市中・南部の平地との気温差 から中生の黄金錦，ヒノヒカリの作付が中心で，こ れらの米は県経済連によって平地の早場米との抱き 合わせ販売が行われてきた。 しかし，近年の米価の 低落基調下において，10 月出荷の中山間地域の米 は, 新潟産などの強力なブランド米と出荷時期が重 なること, 奨励品種として中心的に生産されている ヒノヒカリや黄金錦の知名度の低さにより, 販路確 保が難しいものとなってきた。

1996 年 4 月, 南国市農業委員会より, 地域消費と 直売の拡大, 中山間地域農業の維持などを目指して, 地元の学校給食の食材として, 棚田米の使用が発案 された。これまでも地場産米を学校給食で使用でき

表 2. 南国市中山間地域・生産者の概要（01 年）

\begin{tabular}{lcc}
\hline \hline & 上倉 & 瓶岩 \\
\hline 農家数 (戸) & 80 & 47 \\
米作付面積 (a) & 1652.5 & 988.2 \\
一戸平均 (a) & 20.7 & 21 \\
主要作物 & 水稲・野菜 & 水稲・果樹 \\
\hline
\end{tabular}

出所 : 2000 年農業センサス, 聞き取り調查より筆者作成
ないかという提案は, 農業関係者の中から持ち上 がったことがあった。 しかしながら, 学校給食への 地場産米の導入は，「食料管理法」や，学校給食会 による政府米の一括購入等の慣例的な制度課題，す でに取引のある食材業者との既得権を巡っての問 題, 周辺地域において前例が無いことなどが制約と なり，実現には至らなかった。

現実に取組が進渉し始めたのは，1996 年 6 月，農 協，経済連，市役所など農業関係機関による「南国 市産の米を考える会」の開催からである. 同会では, 棚田米の販路として正式に学校給食の場を活用する 方向が示され，農業関係者の取組推進基盤が形成さ れた，その後，同市農業委員会は，同市教育委員会 に対し，学校給食への棚田米導入を提案した，提案 を受けた同市教育長が食育に熱心な人物で, 給食用 食材の安全性の確保と体験学習等, 教育的効果の観 点から同案に賛同し, 強力な推進者として加わった ことにより，農業及び教育関係者の取組への協同体

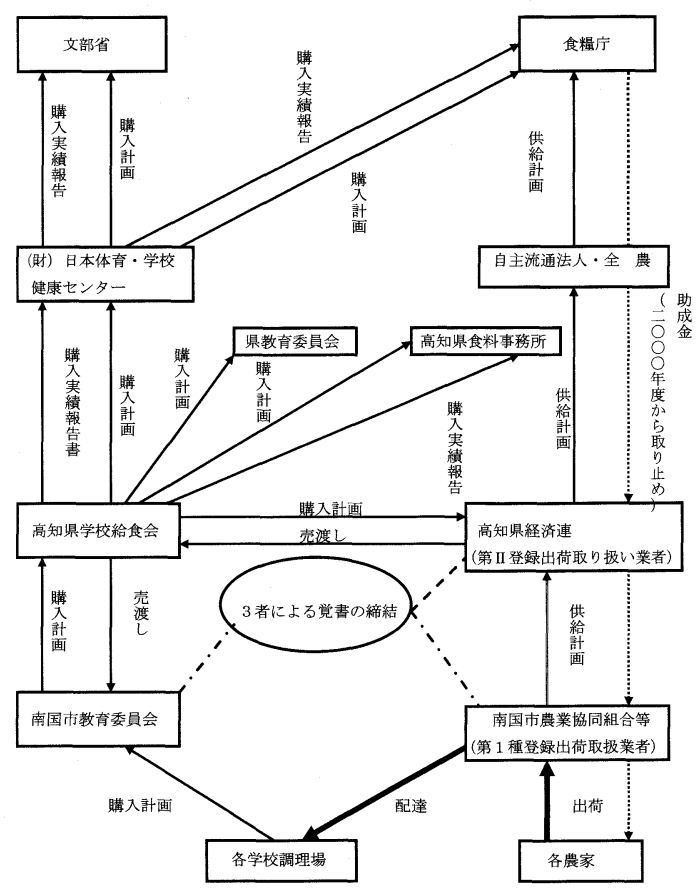

図 2. 南国市学校給食における地元産米利用の流通 経路（1997 年〜 1999 年）

出所 : 南国市農業委員会資料, 参考文献 [3]〔7〕および聞 き取り調査より加筆作成

注) (1) 一物の流れ，(2) ……金銭の流れ，

(3) 一 取引書類の流れ, (4) -ーー 取り決めの締結 


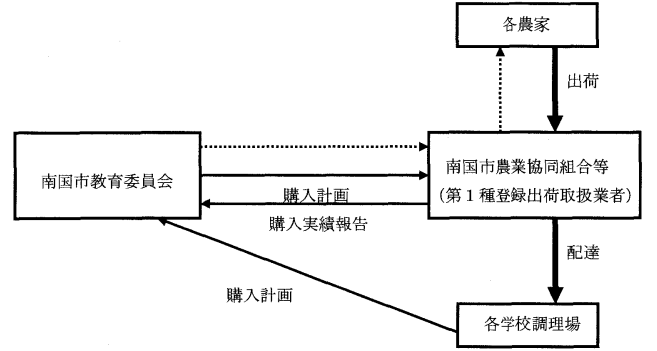

図 3. 南国市学校給食における地元産米利用の流通 経路 (2000 年〜)

出所 : 南国市農業委員会資料，参考文献 [3][7]抽よ゙聞 き取り調查より加筆

注 : (1) 一 物の流れ, (2) …‥金銭の流れ,

(3) 一 取引書類の流れ

制が構築された。

1996 年 10 月, 従来の米購入先であった県学校給 食会を交えて,「南国市学校給食検討委員会」が開 催された。同会では，「学校給食用自主流通米の使 用について」(1996 年) という文部省通達の存在が 追い風となり，これまで米穀を供給してきた県給食 会および県教育課から，全面的に協力するという意 向が示され，具体的な検討が開始されている。この 通達は, 学校給食用米穀助成金の段階的廃止に伴い, 地元の自主流通米を学校給食で使用することを推奨 する主旨の内容で, 流通ルートを切り替える大きな 要因となった。 1997 年 3 月には, 南国市, JA 南国 市, 県経済連の 3 者で, 農業委員会立ち会いのもと, 「自主流通米による学校給食の実施に関する覚書」が 調印され，同年 4 月から，モデル校において棚田米 を使った米飯給食が開始された。

図 2 に, 取組当初の地元産米穀の流通経路を示し ている. 従来経路と異なる点は, これまで米購入の 相手先であった県給食会と折衝した結果, 市独自の $\lceil 3$ 者による覚書の締結」9）を行ったことである. 事 務系統は従来のままで, 物流のルートのみを変更し ての対応である。 2000 年からはJA 南国市に学校給 食米生産部を設立し, 図 3 に示す実質的な関係機関 のみでの物流と事務処理が可能となったことで, 生 産と供給の体制が確立した。

（2）地場産農産物の利用拡大期(1997年8月～2001 年 4 月)

この段階では, 棚田米の供給体制が確立されたこ とで，取組に対する自信を深め，棚田米のさらなる
表 3. 南国市に抢ける学校給食用棚田米の供給量

\begin{tabular}{rrccc}
\hline \hline & 黄金錦 & ヒノヒカリ & その他 & 単位 : $\mathrm{kg}$ \\
\hline 1997 & 8,100 & 21,900 & - & 30,000 \\
1998 & 8,400 & 22,600 & - & 31,000 \\
1999 & 4,500 & 11,490 & 16,010 & 32,000 \\
2000 & 12,610 & 20,730 & - & 33,240 \\
2001 & 11,850 & 22,000 & - & 33,850 \\
2002 & 11,628 & 22,572 & - & 34,200 \\
\hline
\end{tabular}

出所 : 南国市農業委員会資料, 聞き取り調查より筆者作成

利用拡大と米穀以外の地場産野菜の供給が開始され た。

棚田米を使用した米飯給食は，同市公立小学校・ 幼稚園全校の約 3,000 人を対象に, 試行段階を経て, モデル校は週 4〜5 回, その他の学校では, 週 3 回 または週 4 回で開始された. 給食用棚田米供給量は,

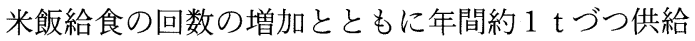
量が増加するなど, 利用拡大の様子が伺える(表 3).

2000 年からは, 地場産野菜の供給が開始され, 市 内農産物直販所「かざぐるま市」および「風の市」 において, 近隣の 5 校の栄養士がその日必要な食材 を一般客と同条件で購入している. 2001 年からは, 地元の有機野菜生産農家と同市学校給食会の契約に よって, 有機野菜の購入経路が確保された，学校給 食用食材は, 通常出荷するものとは別に生産されて おり，2001 年は春菊を，2002 年は大根とニンジン など, できる限り様々な品目を安定的に供給する努 力がなされている. 有機野菜は, 出荷限度量と農家 が一度に直接配送可能な範囲を勘案して，3〜4 校 づつを一グループとしたローテーションで市内全て の給食調理場に供給している.

地場産農産物の供給が本格化してからは,「食材 活用」に関する取組を開始した. 1998 年から市内全 校で家庭用炊飯器による自校炊飯方式が採用され, 棚田米の利点を引き出した効果的な配食法を実現し ている，児童約 17 人に，炊飯器一釜を目安に，市 内全校の小学校と幼稚園あわせて 15 校に対して, 家 庭用炊飯器 270 台と, 調理員の労働軽減の為に洗米 機を一括購入している. 家庭用炊飯器による自校式 炊飯化に伴った設備費用の内訳は，炊飯器代に 466 万円, 施設改修費に 1,838 万円, 電気工事費に 3,200 万円とかなりの初期投資を要したが，JA 南国，JA 長岡, JA 十市より炊飯器 45 台の寄付と農水省の「米 
飯学校給食環境整備支援事業（国庫）」による助成 を受けることができた。このような自校炊飯方式の 維持・管理は, 修理をする際の経費は一台約 1 万円 で, 2000 年の導入から現在まで, 炊飯器の修理は 10 台前後となっており, 初期の設備投資をした後の 経費を低く押さえることが可能となっている.

棚田米の効果的な配食法の考案に続き, 他の地場 産農産物を活用した加工品や献立の開発が行われて いる. 市学校給食会と地元企業が協力して, 特産の ぶどうやすももを使った「まほろばグレープ」(2000 年）「十市のすももちゃん」(2001 年) などデザート メニューを, 献立では地場産野菜の食材交流を行う 千歳市の小学校からのじゃがいもを活用した「海と 大地のなかよしコロッケ」(2001 年) を開発してい る.これらの新メニューの名称は, 市内の小学生全 員に試食をさせてから公募して選考しており，地場 食材や給食に関心を持たせる工夫をしている.

さらに, 地場産農産物の供給と活用が開始によっ て, 1999 年からは市の教育の柱に, 知育・徳育・体 育の三領域に，新たに「食育」を加え，学校給食を 核にした食農教育活動の推進が図られている. 取組 は，大きく三つの形態に分類できる．第一は，学校 主体による体験学習である。味噌やこんにゃく, 豆 腐等昔ながらの加工品作りや郷土料理の皿鉢（さわ ち）作りを行い, 地場産農産物や地域文化に触れる 「伝統食づくり」や，学校・学年を超えた体験学習 として, 地元中・高連携による手作り味噌, 小・中・ 高校連携のお茶づくりが行われている。味噌は, 給 食に使用される全量を栄養士や中高生が作ったもの を含め手作りでまかない, 生産された約 $300 \mathrm{~kg}$ の 緑茶は, 給食や行事, 職員室などで使用されている.

第二は，農業関係機関による生産現場での体験学 習を中心とした食農教育活動である. 1997 年から地 元 JA を中心として, 市内の小学校 5 年生と保護者 を対象にした「米づくり親子セミナー」を開始して いる. 地域農業への理解促進や意識啓発を目的に, 学校給食用棚田米の生産地域をフィールドに, 稲作 やそれにまつわる事柄についての簡単な学習, JA や 県経済連のライスセンターの見学, 田植えや稲刈り, 交流施設「梅星館」で農家との交流を行っている. それによって, 学校給食米である棚田米の生産現場 を親子で確認し，農業への知識と認識を深めている. また,「米づくり親子セミナー」で収穫した米を給
食に使い，児童と農家が会食する「交流給食」が実 施されている. 会食に先立ち, JA 職員や普及セン ター職員が講師として, ビデオや展示物を使いなが ら, 学習田の米の成長や, 体験学習について振り返 り, 生産農家の苦労話を織り交ぜながら, 子供たち の理解を促す工夫をしている.

第三は，栄養士による学校給食と連動した食育活 動である. 通常の給食では, 栄養職員部会が作成し た「放送資料一ロメモ」を使用した放送や，食材産 地等の情報を盛りこんだプリントの配布によって, その日の給食についての予備知識や説明を行ってい る. 教科と連携した食教育では, 1997 年から家庭 科, 社会科等の時間に打いて, 学校栄養士と担任教 師とのティームティーチングが開始されている. 学 習内容は, 平素の授業内容に地域の食文化や学校給 食などの要素を付加したもので, 栄養士の専門知識 によって, 子供達の深い興味関心を引き出すことに 寄与している. 栄養士不在の学校へは派遣して授業 を行うなど, 取組に積極的な学校のみならず，市内 全域の食教育に努めている.

\section{（3）地産地消コンセプトの明確化と普及段階 (2002 年〜)}

2002 年からは, 南国方式の学校給食が「地産地 消」「食育」というコンセプトを伴って定着した段 階である. 2003 年に市内全校が完全米飯給食化した ことで, 地産地消に関する取組の定着と拡大につな がった．同年から市農林課による地産地消促進事業 が開始され, 市内全域で地産地消に関する取組が展 開されている. 同事業では, 市内 11 小学校を対象 に稲作および畑作の実習と収穫物の調理を行う体験 農園活動, 幼稚園児と保護者を対象に地場産農産物 を使用した親子料理活動，農産物直販所「風の市」 に生産者の顔写真を入れたパネル設置などの支援活 動を行っている.

同市の地場産農産物の給食使用や食農教育に関す る取組が前例となり，周辺他地域への普及や政策的 に評価が高まっている. 2000 年から高知県議会の答 弁において南国市の事例が再三取り上げられ 10), 2002 年度には須崎市, 2003 年度は高知市が学校給 食への地場産米導入を開始している. 高知県庁に 2003 年度から「地産地消課」が発足し, 南国方式は 県内全域に普及しつつある。

更に, これまでの取組を深めるべく, 2004 年から 


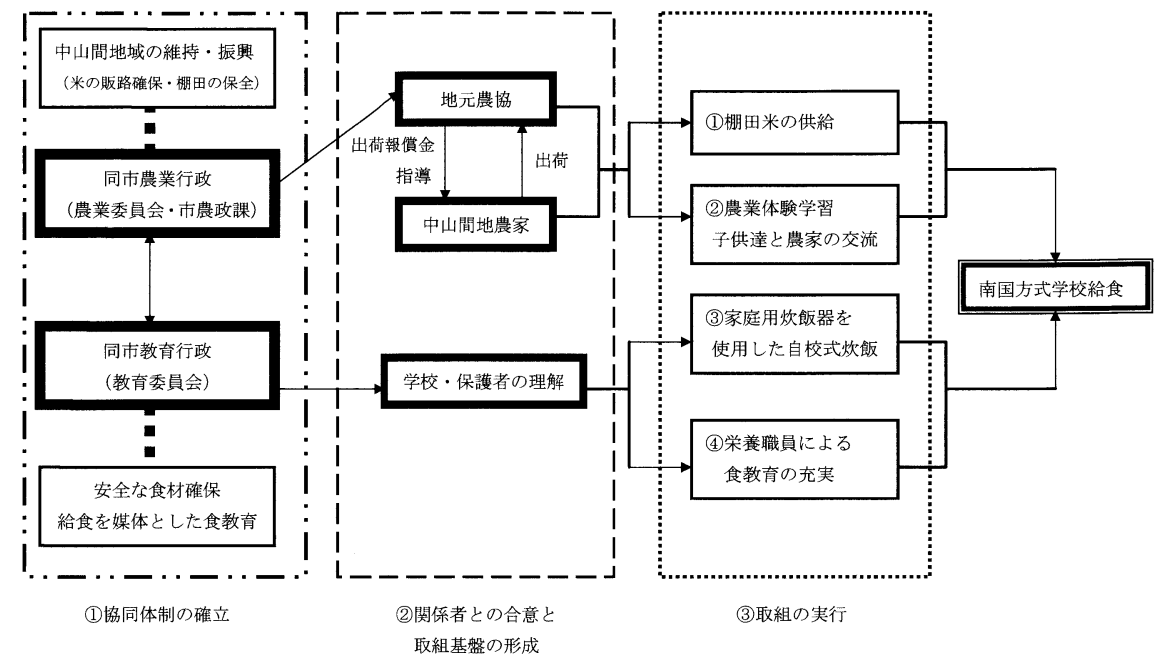

図 4. 南国方式の取組構造 出所：聞き取り調査により筆者作成

は地場産野菜の量と質の確保へ向けた関係機関によ る協議会の設立や，食育指導の充実とカリキュラム 開発を行い, これらの成果を「南国食育フォーラム」 において情報発信をするに至っている。

取組を総括すると，図 4 に示すように，農業関係 者は, 米穀の販路確保と地域農業の維持・振興を, 教育関係者は, 安全性の高い食材の確保と教育効果 を目的とし, 学校給食への地場産棚田米の導入とい う共通の方策で合致して，機関を越えた協同体制を 確立している．協同体制が確立した後は，各機関に おいて関係者への理解を促し, 役割分担と連携を絡 めながら南国方式学校給食を形作っている. 以上の ことから, 南国方式の学校給食は, 地域農業を象徵 する「棚田米」を核に展開をしたことで，地域内連 携を実現し, 他の地場産農産物の導入や食教育活動 などの取組が広がったと言える。

\section{4. 南国方式の取組に見られる効果の考察}

前節に示したように, 南国方式の取組は進展する に従って注目を集めている，それは，同取組に見る べき効果があったからである，そこで本節では，同 市の取組から現れた効果と, 効果とともに表出する 課題を明らかにする. 問題の整理に際し, 学校給食 における地場産農産物の活用から望まれる主な効果 を，(1)地産地消効果，(2)流通経路創出効果，(3)食農 教育効果の三分類した．この分類は，参考文献 [3]
において事項毎に列挙していた同市の取組に対する 評価を踏まえて, 南国方式の特徵から抽出される効 果を大別した結果である，以上の分類に従い，同市 の取組から生まれる効果を検討する.

第一に, 取組によって地域内自給率の向上，農業 生産の維持向上による環境保全効果, 地域内コンセ ンサスの醸成などの地産地消効果があったと言え る. 地元の米を地元の学校で消費する南国方式によ り, 系統出荷される同市中山間地域米の販路が一挙 に獲得された，そして学校給食への棚田米導入の成 功により, 他の地場産野菜の供給が開始され, 地産 地消が拡大している.

地場産野菜の供給が加わって 2 年が経過した 2002 年度の米穀は，南国市産を $100 \%(3,860$ 万円）使 用するに至っている. 青果物に打ける南国市産の割 合は, 58.7\%（1,319 万円）, 続いて県内産は 22.7 \%（510 万円）の地場産物を使用している. 市内産， 県内産を合わせると, 約 $80 \%$ の高い地場産農産物の 使用割合は, 取組による地産地消の進展を示すもの と言える.

そして学校給食米生産の供給を契機に, 学校や子 供たちとのつながりができたことによって, 中山間 地域の活性化に関する取組が萌芽している．地域グ ループが活気付き, 特産品である四方竹, 炭焼き, キジの飼育, 棚田のオーナ一制度に付随した体験活 動「棚田お米学校」(2000 年〜) が開始されている. 
表 4. 学校給食米・出荷農家手取金額の推移 単位: 円 $/ 10 \mathrm{Kg}$

\begin{tabular}{cccc}
\hline \hline & 玄米価格 & 出荷奨励金額 & 農家手取 \\
\hline 1999 & 2,896 & 310 & 3,206 \\
2000 & 2,783 & 335 & 3,118 \\
2001 & 2,705 & 310 & 3,015 \\
2002 & 2,495 & 198 & 2,693 \\
\hline
\end{tabular}

出所：南国市農業委員会資料, 聞き取り調査より筆者作成

交流活動を通じて給食米生産者には「子供たちが食 べる米を作る」という意識が生まれ，農法に関して 具体的な取決がなくても, 農薬を年 2 回, 化学肥料 を 1 回程度と, 従来と比較して低減している. これ らの過程は，学校給食における地産地消に関する取 組が，地域活性化や環境保全に寄与した成果と言え よう.

同市棚田米の学校給食への使用は当初, 中山間地 域米の安定的な販路確保と稲作振興対策として効果 を挙げてきたが, 一方で, 学校給食米に出荷するメ リットの低減が表面化してきた. 表 4 に, 出荷農家 手取金額の推移を示している. 玄米価格の低落と共 に，出荷奨励金額も減少しており，1999 年には 310 円だった出荷奖励金が, 2002 年には 198 円となるな ぞ, 給食米へ供給するメリットが年々薄れつつある.

第二に，学校給食における地場産農産物の流通経 路創出効果が挙げられる.これまで学校給食用食材 における青果物の供給は, 青果業者に限定されてい たものが, 2000 年からは直販所, 2001 年からは契 約有機農家など新しい食材購入経路が生まれている （図 5), 表 5 で, 2002 年の地場産青果物の供給割合
を見ると, 最も多く青果物を供給しているのは業者 による集荷で $57.5 \%$ ，続いて JA 直販所が $1.9 \%$, 契 約有機農家は $0.6 \%$ である．給食用食材に占める新 規購入経路の占める割合は小さいながら, 購入経路 の選択肢の増加は, 青果物の学校給食市場を占有し ていた業者にある種の緊張感を与えたのである.

青果業者の変化は, 月 1 回の購入計画会議の際, 業者側から食材購入や献立に関しての提案が出され ることに現れている．業者は，なるべく無農薬や減 農薬など安全性の高い地場産農産物の集荷に努め, 時には旬の時期に入った方が安価に食材購入できる ので，設定している献立をずらして対応すれば良い などの意見も出されるという。このような業者の変 化は，南国市が「食育」や「食材の安全性・地域性」 といった大方針を打ち出したこと対する業者側の対 応と言える. 結果として先述した南国市産と県内産 を合わせて $80 \%$ に達する高い地場産野菜の使用割合 の実現と，地域市場の拡大につながっている.

新規購入経路は, 既存の購入経路への影響をおよ ぼす一方，供給方法と農家利益の面で課題を残して いる，学校給食用の有機農産物の価格は，青果物集 荷業者の卸值と同水準に設定されている. 中間業者 が介在しないことによる利益はあるものの, 通常の 営農活動に加えて, 複数の学校への指定時間内の配 送や伝票処理等の作業は個別農家にとって大変なも のであり，労力に見合った対価が価格に反映されて いるとは言い難い，そのため，学校給食用の有機栽 培は生産者層に広がらず，ボランティア的供給に支 えられているのが実状と言える。

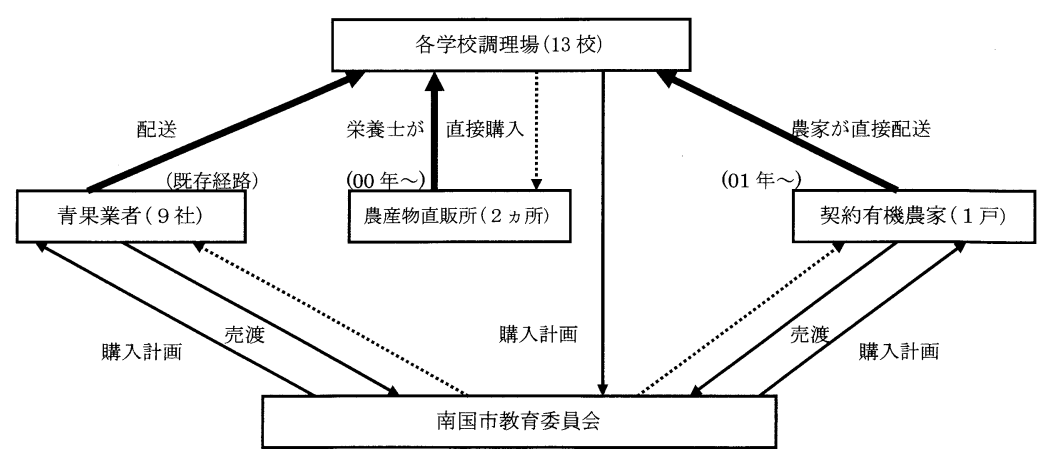

図 5. 南国市における地場産野菜購入経路

出所：聞き取り調查により筆者作成

注 : (1) 一 物の流れ, (2) 一 金銭の流れ, (3) ……取引書類の流れ 
表 5. 南国市における学校給食用地場産農産物の現状（2002 年）

\begin{tabular}{|c|c|c|c|c|}
\hline & 米 & \multicolumn{3}{|c|}{ 青果 } \\
\hline & $\begin{array}{l}\text { 学校給食米 } \\
\text { 生産組合 }\end{array}$ & $\begin{array}{c}\text { 青果業者の } \\
\text { 集荷によるもの }\end{array}$ & $\begin{array}{l}\text { JA 直販所 } \\
\text { (かざぐるま市, } \\
\text { 風の市) }\end{array}$ & $\begin{array}{c}\text { 契約有機農家 } \\
\text { (ニモちゃん農園 } \\
\text { グループ) }\end{array}$ \\
\hline 生産地域 & $\begin{array}{l}\text { 上倉地区 } \\
\text { 瓶岩地区 }\end{array}$ & - & 南国市内 & 長岡地区 \\
\hline 生産者数 & 60 名 & - & $\begin{array}{l}\text { かざぐるま市 : } 232 \text { 名 } \\
\text { 風の市 : } 297 \text { 名 }\end{array}$ & 1戸（3名） \\
\hline 生産者の性格 & $\begin{array}{l}60 \text { 代, } 70 \text { 代の農家 } \\
\text { が中心 }\end{array}$ & - & $\begin{array}{l}50 \text { 代, } 60 \text { 代の農家 } \\
\text { が中心, 規模は様々 }\end{array}$ & $\begin{array}{l}5 \text { 人家族, } 56 \text { 歳, 夫婦 } \\
\text { と長男で農業専業 }\end{array}$ \\
\hline 農法 & 減農薬・減化学肥料 & - & $\begin{array}{l}\text { 減農薬の申し合わせ } \\
\text { あり }\end{array}$ & 有機農法 \\
\hline 給食用食材に占める割合 & $100 \%$ & $57.53 \%$ & $1.89 \%$ & $0.59 \%$ \\
\hline 給食配食時の工夫 & $\begin{array}{l}\text { 家庭用炊飯器にて } \\
\text { 提供 }\end{array}$ & - & $\begin{array}{l}\text { 給食時に校内放送 } \\
\text { で生産者名などの } \\
\text { 情報提示 }\end{array}$ & $\begin{array}{l}\text { 給食時に校内放送で } \\
\text { 生産者名などの情報 } \\
\text { 提示 }\end{array}$ \\
\hline $\begin{array}{l}\text { 地場産農産物とリンク } \\
\text { た教育・交流活動 }\end{array}$ & $\begin{array}{c}\text { 米づくり } \\
\text { 親子セミナー } \\
\text { ・棚田お米学校 }\end{array}$ & - & $\begin{array}{l}\text { 近隣小学校の児童 } \\
\text { が直販所の見学 } \\
\text { (風の市) }\end{array}$ & $\begin{array}{l}\text { 小学校での出張授業 } \\
\text { (大篠小, 御免野田小 } \\
\text { など） }\end{array}$ \\
\hline
\end{tabular}

出所：聞き取り調查（南国市農業委員会，南国市農林課，南国市教育委員会，JA 南国市）より筆者作成

注 :「給食用食材に占める割合」は, 全給食用青果物に占める南国市産青果物の割合を, 同市教育委員会 資料及び市況等から，金額べースで試算したものである.

直販所での地場産野菜購入については，予想以上 の直販所の盛況によって, 学校給食用に別途対応す ることが困難になっており，導入に向けた模索が続 いている. 現在, 地場産農産物の使用は, 直販所近 くの 5 校で行われているが, 使用量や金額が小さい ことから, 供給体制の整備が立ち遅れる結果となっ た.

経済的メリットの低さと，取組を継続していく 「担い手」の問題は, 学校給食米と地場産野菜の供 給，どちらにも指摘できる. 2003 年からの完全米飯 給食化に伴い, 3,000 人分週 5 回の学校給食に対応 するには, 両地区での米収穫量の半数以上の米穀が 必要である. 給食米生産組合が結成されて以後も, 市農林課や JA が, 農家に対し縁故米を減らし，学 校給食用に出荷するよう, 啓発パンフレットを発行 するなど供給に向けた対策を続けている. このよう な対策を行うのは, 学校給食米の出荷が従来と同じ く農協に対して行われるため, 多くの生産者には学 校給食米生産者としての実感が伝わらず，交流施設 の運営や体験活動に直接携わらない生産者の取組へ の参加意識が薄いためである. 地場産農産物の供給 など取組を担ってきた意識の高い中核層の高齢化 と, それ以外の層への意識定着が難しい状況から,
給食用農産物の供給者確保は切実な課題である.

第三に, 一連の取組から, 食農教育効果の発現が 挙げられよう. 同市教育委員会のアンケートによる と, 従来の米飯給食は, パン納入業者に炊飯と学校 への配送を委託していたため, 食べる頃には冷めて おいしくないという児童の反応と, 残食が多いとい う欠点があった．家庭用炊飯器による自校炊飯方式 に変わってから, 棚田米に付加価值をつけた「配食 法」となり, 持ち運びが容易である, 家庭的な雾囲 気である, 温かくおいしい, 生産地や生産者が見え ることから, 残食が極めて少ないなどの成果が見ら れている.

「親子セミナー」や「交流給食」などの棚田米生 産者との交流活動,「かざぐるま市」「風の市」への 見学や，契約有機農家による出張授業は，地域の特 色を反映した体験学習と日常の給食とを連関する機 会として認知されている。 これら学んできた食教育 の知識が, 家庭へフィードバックし, 家庭の夕食で 栄養に関する指摘をする子供がいることなど，単に 地場産物を供給するだけではない食農教育効果が現 れている.

食農教育効果を重視したことは, 波及効果が生ん でいる. 家庭用炊飯器による自校式炊飯への切り替 
えは，給食の米飯がおいしくなっただけではなく， 業者に炊飯を委託した場合, 一食あたり 47 円のコ ストがかかっていたものが, 17 円まで削減され，南 国市 3, 200 人の児童 1 回の給食で, 10 万円近くの経 費が節減され, 年間にすると 1,500 万円近くの節約 となった. 米購入補助金打ち切りによる差額分に対 応できる余裕だけではなく, さらに 1999 年から給 食費を 5 円下げることが可能となった.

給食を媒体とした教育活動の進展によって, 食農 教育効果や副次的効果を生んでいるが, 現場におけ る指導体制の課題が挙げられる. 農業体験指導は, 棚田米生産者や農業関係機関の担当者, 教育現場に おける食教育は，栄養士や熱意のある一部の教員に よって担われている. これらの指導層, 特に取組当 初から関わってきた棚田米生産者の高齢化による参 加頻度の低減や活動の制約，農業関係機関担当者の 配置転換, 現場教師の取組への参加意識の違いは, 取組水準の変動をもたらしている. 南国方式が, 今 後より一層の効果をあげるには，農業関係者および 教育関係者の各構成員が, 互いの部局の役割や置か れている状況を理解し合った上で，一部に因らない 指導体制を形成することが求められる.

\section{5. むすび}

以上では，学校給食における地場産農産物の活用 に焦点をあて, 南国方式の学校給食の展開過程と効 果の考察を行った。同市では, 取組の合意と制度形 成期において, 棚田米の導入を既存経路の裁量範囲 内で物流のみを切り替えて開始し，生産体制を制度 的に確立してから新経路の形成を実現している.こ の過程において, 異なる分野である農業関係機関と 教育関係機関が協同体制を形成し，既存経路からの 変更を関係機関に対して粘り強く折衝したことが取 組実現の要因となった。地場産農産物の利用拡大期 においては, 地域農業の課題を象徵した棚田米に 「山のお米を怙家の炊飯器で炊く」という「物語性」 を付加した家庭用炊飯器での自校炊飯方式によっ て, 学校給食における地場産農産物の有効な配食法 を実現している，効果的な配食法は，子ども達に一 般農産物と地場産農産物を差別化する効果を生み, 地場産農産物を使用する意義を浸透させ, 利用拡大 を図る有効な手法となった。地産地消コンセプトの 明確化と普及段階においては, 給食と生産地を結び
つけた食農教育の推進が，取組全体に「食育」「地 産地消」というコンセプトを持って推進される要因 となり，地域内および他地域への取組の波及につな がっていることを明らかにした.

同市における今後の課題として, 地場産農産物を 学校給食に供給する農家の問題が残る. 南国市の取 組実態は, 棚田米供出による手取金額が年々低減し ていること, 契約有機農家は青果業者と同額で給食 用食材を卸している状況であることなど，地域農業 者の「好意」に支えられている面が大きいと分かっ た. しかしながら, 前述した課題はありながらも協 力する農家は, 農産物供給に留まらず, 体験学習や 出前授業の講師としての役割も担っていることか ら, 取組の根幹を支える存在に他ならない。これら の協力的な供給者の生産物と好意を, 行政や組合な ぞ農業関係機関のみならず教育関係機関が相互理解 を深めた上で, 協同して価格面, 集荷・配送などの 面でバックアップすること, 意識啓発に一層努める ことが, 担い手層の拡大と取組継続になり, その結 果として地域農業の振興や食育の推進につながると 言える.

近年の学校給食を取り巻く環境は, 南国市のよう に地域振興や食育の観点から地場産農産物の活用を 推進してゆく傾向と, 財政削減と合理化の観点から 調理業務の民間委託を推進する傾向とが並列してい る. 調理業務の民間委託について紙数の制限で詳細 は割愛するが, 労働派遣法により栄養士から委託調 理員に対する指示が制限されるなど指揮系統の課題 があること, 利益追求の企業性から地場産農産物が 使用されにくい環境になること, 退職者補充を委託 調理員で充てている形式では経費削減効果が歴年を 経てからではないと現れないことなどが指摘されて いる. 前述した指摘から, 東京都杉並区をはじめ各 地で保護者や市民団体の運動が見られる ${ }^{11)}$ 。これ らの動きを踏まえ, 財政削減と食教育をどう調和さ せるかが今後の課題になると指摘できる.

このような状況下に打いて, 南国市のように, 教 育と地域農業の課題に真摰に目を向け, 従来の制度 と新しい取組を組み合わせて対応した結果, 経費削 減効果と食育を成立させている自治体もある. 同事 例より,地場産農産物を活用した学校給食の取組は, 学校給食の二つの方向性に自治体が思案する中で, 大きな示唆を与えるものである. 食育や地域振興な 
ど将来の効果に期待した演繹的視点に立ち, 各自治 体の自主性によって, 地域農業の実態に即した地場 産農産物の供給と教育的な活用策を模索することが 肝要である. 以上のことから，現在も過渡的段階に ある南国方式の推移を注視してゆく必要があるだろ う.

注１）「地場産」とはどの範囲を指すのか, しばしば議論にな る. 藤島・山本ら〔7]は，小規模野菜生産地の流通問 題の観点から，地場流通は流通の拠点となる卸売市場 を中心に半径 $50 \sim 60 \mathrm{~km}$ の範囲で生産され，その域 内へ仕向けられる流通および, 生産者グループなどに よる地域の自主的流通を指している，中村〔2]は，学 校給食での地場産食材率向上の観点から, 自治体（市 町村）内部で生産された農産物を指している. 先達の 地場産の定義を踏まえ，本稿における地場産の範囲は， 「学校給食の実施主体である当該学校給食会の範囲で 生産される農産物」と定義する。

2）一般的に「地産地消」とは，「地場生産一地場消費」を 意味する略語である，その意義として，(1流通コスト の削減，(2)消費者，生産者の相互理解，(3)遠隔輸送に より発生する環境負荷の軽減, (4)地域内自給率の向上, (5)農業生産維持・向上による環境保全効果，(6)地域内 コンセンサスの䁔成などが挙げられる.

3） 2003 年度から文部科学省では，学校給食用食材の安全 性の確保を目的に, 都道府県に食材選定や検查体制の 調査を主軸としたモデル事業を委託している，この中 で, 安全な食材確保策として, 地場産農産物の利用を 推進している。「学校給食食材を安全に」『日本農業新 聞』 2002 年 9 月 8 日を参照されたい.

4）第 159 回通常国会首相施政方針演説の中で，教育の柱 に「知育・体育・徳育」の産領域に加え，「食育」の推 進を表明している．自民党で食育調査会が編成され， 「食育基本法」成立を目指しており，学校給食における 地場産食材の使用割合の数值目標を設定している.「食 育基本法計画に目標値」『日本農業新聞』2004 年 1 月 31 日を参照されたい.

5）地場産物を使用した学校給食に関する報道，調查研究 は近年多く見られるが，紙数の制約により全ては紹介 できない. 大要が分かるものとして，「特集わが町の特 産物を生かした「学校給食」」『農林統計調査』pp. 437,11 号 (2003 年), 参考文献 [8]などを参照されたい.

6)「南国方式」学校給食の取組は，すでに多くのマスメ ディアで取り上げられている．筆者による新聞検索で は，地元の『高知新聞』(50 件) を筆頭に，『日本農業 新聞』(32 件),『読売新聞』(15 件), 他地方紙 (18 件), 『朝日新聞』( 6 件), 『日本工業新聞』(1 件) の計 122
件にのぼる，主な雑誌に，現代農業〔5〕では同市農業 委員会の取組を中心に, 草創期について特集が組まれ, 鈴木〔6]による棚田米生産者の意識調査では地域農業 と学校給食の連関について報告されている．検索には 日本経済新聞社のデータサービス「日経テレコン 21 」 を利用し，1996 年から 2004 年までの収録全新聞を対 象に「南国市」「学校給食」というキーワードを用いて 2004 年 5 月 20 日に検索した結果である.

7）学校給食に関する統計資料は，参考文献 [4]および文 部科学省体育局「学校給食実施状況調査」を引用して いる.

8）荷見〔10〕は 1980 年代にいち早く学校給食へ地場産農 産物，とりわけ有機農産物の導入を食農教育，地域農 業構造への波及効果の点に意義があるとして提唱して いる. 当時から，有機農業運動と結びついた取組が見 られたが，一部の積極的な地域に留まり，大きな流れ には 1990 年代後半までならなかった. 学校給食を考え る会の活動 (://www1.jca.apc.org/kyusyoku 2004 年 6 月 現在の URL) など参照されたい.

9）正確には「南国市学校給食米壳買契約書」として，南 国市長，南国市農業協同組合長，南国市農業委員会会 長の三者で取り交わされたもので，内容は契約物資の 品名や購入条件，納入期日場所について売買契約が締 結されている.

10）高知県議会議事録，第 256 回（00 年 6 月定例会)，第 263 回 (2001 年 9 月定例)、第 268 回 (2002 年 6 月定 例会)、第 271 回 (2003 年 2 月定例会)

11） 03 年度現在, 学校給食調理業務の民間委託は $15.2 \%$ と なっている. その一方で, 茨城県古河市では食育効果 の高い地産地消型給食を行いやすい環境整備として, あえて自校式調理へ転換している. 民間委託化に関し， 行政問題からの文献として，二宮厚美『自治体の公共 性と民間委託 : 保育・給食労働の公共性と公務労働』, 自治体研究社，（2000 年）等を参照されたい．

（付記）

本稿は（株）ヤンマー農機主催「第十二回ヤンマー 学生懸賞論文」著者大賞作「農と食をつなぐ学校給食 一高知県南国市の棚田米を使った取り組み一」および 参考文献〔3〕を全面加筆・修正したものである，本稿 作成に際し，貴重な時間を割いて調査協力して下さっ た南国市農業委員会，同市教育委員会，JA 南国市，高 知県庁，二モちゃん農園グループの皆様，多くの教示 を与えて下さったレフェリーの先生方, 根気強く指導 して下さった胡柏先生に心からの感謝を申し上げま す. 


\section{参考文献・資料}

〔1〕根岸久子「ライフスタイルの転換と食一農との新しい 結びつき」『農林業問題研究』地域農林経済学会, 第 145 号 (2002), pp. 177-186.

〔2〕中村 修・秋永優子・田中理恵 ・ 辻林英高・川口 進 「学校給食の地場産自給率に関する研究」『長崎大学総 合環境研究』長崎大学環境科学部, 第 6 巻第 1 号 (2003), pp. 89-112.

〔3〕片岡美喜・胡柏「農と食をつなぐ学校給食の取組 と効果一高知県南国市を事例として一」『愛媛大学農学 部紀要』愛媛大学農学部, 第 47 号 (2002), pp. 21-28.

〔4〕胡柏・片岡美喜「学校給食における有機農業と地 産地消の世界一愛媛県今治市の取組みを中心として 一」『農林統計調査』(財) 農林統計協会, 3 月号 (2003), p. 9-16.

[5]『平成十三年版学校給食要覧』日本体育・学校健康セン ター, 2002.

[6]「「山の抢米」で学校給食一“与えられる給食”から“地
元でつくりあげる給食”へ一高知県南国市の取り組み」 『現代農業』農文協，11月号 (1999)，pp. 314-330.

〔7〕鈴木邦子「農」『地域農業と教育が作る学校給食一高知 県南国市の学校給食供給事例より一』財団法人農政調 査委員会, No. 254 (2000), pp. 2-39.

８８藤島廣二・山本勝成『小規模野菜産地のための地域流 通システム』(財) 富民協会, 2000, pp. 9-11.

（9）竹下登志成『学校給食が子供と地域を育てる』自治体 研究社, 2000 .

[10〕荷見武敬「学校給食を考える」『協同組合経営研究月 報』協同組合経営研究所, 340 号 (1982), pp. 14-20.

[11〕片岡美喜「地場産農産物を利用した学校給食の展開と 効果」『日本農業教育学会誌』日本農業教育学会, 第 33 号・別号 (2002)， pp. 47-50.

〔12〕片岡美喜「農と食をつなぐ学校給食 - 高知県南国市の 棚田米を使った取り組み」『第 12 回ヤンマー学生懸賞 論文・作文入賞作品集』ヤンマー農機株式会社, 2002 , pp. 13-26.

（受理日：2005 年 2 月 14 日） 